\title{
MORPHOMETRIC STUDY OF FEMORAL NECK SHAFT ANGLE AND ITS CLINICAL SIGNIFICANCE
}

\section{Aparna Gullapalli *1, Anil Kumar Inuganti ${ }^{2}$.}

${ }^{{ }^{1}}$ Associate Professor, Department Of Anatomy, NRI Medical College, Guntur, Andhra Pradesh, India.

${ }^{2}$ Associate Professor, Department Of Anatomy, KIMS Amalapuram, And hra Pradesh, India.

\section{ABSTRACT}

Back ground: Exact knowledge of femoral neck - shaft angle (NSA) is important in recognizing, understanding and treating pathology conditions in the hip Joint. The purpose of this study is to evaluate neck shaft angle of femur correlated with number of clinical aspects.

Materials and Methods: The NSA was determined in 110 femur in the department of anatomy; NRI medical college; Guntur Dt. and in department of anatomy, KIMS Amalapuram, Andhra Pradesh, India.

Results: Out of 110 specimens; $70 \%$ shows normal angle and remaining $40 \%$ showed difference that is more (or) less than normal angle.

Conclusion: This study is very important orthopedic surgeons \& also to neurology, anthropological practice.

KEY WORDS: Femur, neck axis, shaft axis, neck shaft angle (NSA).

Address for Correspondence: Dr. Aparna Gullapalli, Associate Professor, Department Of Anatomy, NRI Medical College, Guntur, Andhrapradesh-522503, India. Mobile: 9502310954

E-Mail: maildraparna@gmail.com

\begin{tabular}{|c|c|c|}
\hline \multicolumn{3}{|c|}{ Access this Article online } \\
\hline \multirow{3}{*}{$\begin{array}{l}\text { Quick Response code } \\
\text { DOI: } 10.16965 / \text { ijar.2017.301 }\end{array}$} & \multicolumn{2}{|c|}{$\begin{array}{l}\text { Web site: International Journal of Anatomy and Research } \\
\qquad \text { ISSN 2321-4287 } \\
\text { www.ijmhr.org/ijar.htm }\end{array}$} \\
\hline & $\begin{array}{l}\text { Received: } 16 \text { June } 2017 \\
\text { Peer Review: } 16 \text { June } 2017\end{array}$ & $\begin{array}{l}\text { Accepted: } 10 \text { Jul } 2017 \\
\text { Published (O): } 31 \text { Aug } 2017\end{array}$ \\
\hline & Revised: 21 June 2017 & Published (P): 31 Aug 2017 \\
\hline
\end{tabular}

\section{INTRODUCTION}

The femur is largest \& strangest bone in human body. It consists of proximal end, shaft \& distal end. The proximal end of femur has much attention. The knowledge of its anatomy is important in treatment of pathology conditions of the hip \& femur.

The NSA is the angle formed by shaft axis \& weak axis of the femur. The angle is also named as caput collum diaphysis (or) cervico diaphyscal angle (CCD) [1]. The neck axis is the line drawn from the centre of the femoral head to the centre of the femoral neck at the narrowest part of the neck. The shaft axis is line drawn from the middle of the femoral condyles to the middle of the greater trochantar in two planes. This corresponds to "Ideal Axis" by Billing \& long axis by Norman [2,3].

Reikras $O$ etal modified Dunlap/Rippstein method [4-6]. The accuracy of the method was within +/- 7 degrees for the anteversion angle and within -5 to +9 degrees for the head-neckshaft angle.

Chevrot's method was described by Chevrot [7] in 11 dissected specimens using a Philip diagnost $\mathrm{N}$ to obtain angulations of the central ray. This method had a precision that was significantly poorer than the Dunlap/ Rippstein 
method ( $p$-value less than 0.01 by the F-test) According to Ian Gilliam et al [8], did work on NSA in humans: variation relating to climate, clothing, sex, lifestyle, age, side. According to him, the NSA of modern human between 120 to 140 degrees. The averages NSA among modern humans of 127 degrees markedly lower than the average angle 135 degrees quoted in Gray anatomy (standing 2008)[9].

Rickles, T; et.al [10] compared young and old adult patient's FNS angles and determine if a statistically significant difference exists between both age groups and additional focus will be given to look at male and female groups within each age category to see if age related changes affect the two gender groups differently.

The range of normal femoral neck ante version in adult population and to draw the relationship between the preoperative, biplane $\mathrm{X}$-rays and clinical methods were carried out by Maheshwari, AV et.al. [11]

The FNA is result of fetal development, heredity, mechanical forces, and intra uterine position [12].

In the normal hips, the NSA should cause the longitudinal axes of the femoral necks to cross at the point of body weight.

The enlargement \& maturation of the hip joint increase at $20^{\text {TH }} \mathrm{wk}$. of gestation and the NSA ravages from $135^{\circ}-140^{\circ}$ at birth [13].

The life time risk of osteoporosis related fractures in the hip, spine and wrist is considered to be $30-40 \%$ in women and $13-20 \%$ in men[14].

The angle increase with cerebral palsy when compared to angles of healthy children (15).

\section{MATERIALS AND METHODS}

A total of 110 dry femora collected from department of anatomy of NRI medical college, chinnakakani, Guntur and KMIS Amalapuram, Andhra Pradesh, India.

The study of NSA of femur started with the following methods - (Fig. 1 and 2).

1. Collection of 110 adult dry femora.

2. White drawing sheets, sketch pen, pencil, scale.

\section{Goniometer}

Fig 1 and 2: Showing calculating the NSA.

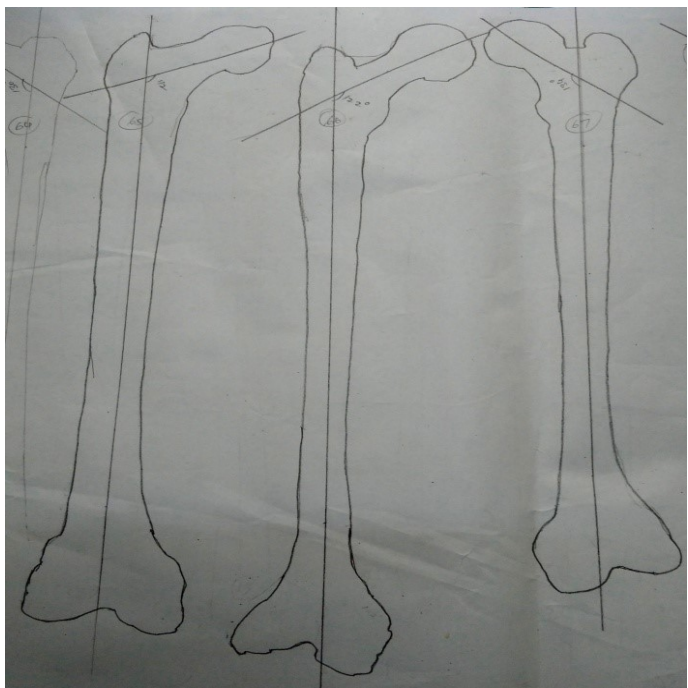

Fig: 1

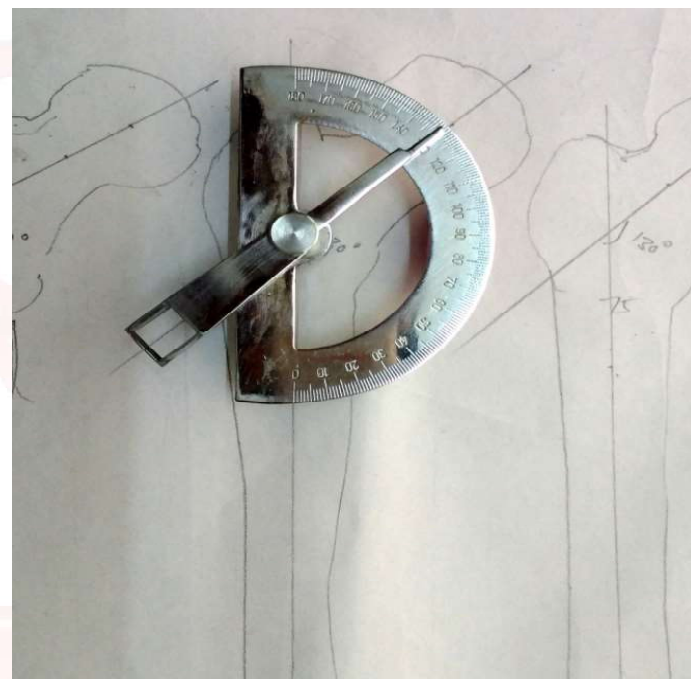

Fig: 2

NSA of femur is defined as angle made by long axis of shaft and long axis of neck. This angle is measured by using goniometer. The two axis were drawn on the sheet and take the NSA angle with goniometer by keeping the goniometer parallel to shaft axis (method was described by Radha Pujari [16].

\section{OBSERVATIONS}

The present study showed neck shaft angle in 110 specimens, out of which 60 are left, 50 are right (Table1).

Table 1: Showing left and right femurs NSA and their standard deviations.

\begin{tabular}{|c|c|c|c|c|}
\hline Neck shaft angle & $\begin{array}{c}\text { No. of } \\
\text { samples }\end{array}$ & Method & NSA & SD \\
\hline On Left side & 60 & Dry bones & 1230 & 10.8 \\
\hline On Right side & 50 & Dry bones & 1190 & 17.15 \\
\hline \multicolumn{3}{|c|}{ Average of left \& Right $121^{\circ}$} & & \\
\hline
\end{tabular}




\section{DISCUSSION}

The angle of inclination is NSA was approximately 125 degrees. This angle is essential in the diagnosis of various pathological conditions of hip and femur including developmental dysplasia of the hip (DDH) $[17,18]$, cerebral palsy in children.

According to Christoph kolja boese, [19] the mNSA on rt. 163.50 and on It. 162.20. The NSA in children and in early fetal life is 160 degrees (Humphery and Friend langer) [20].

The angle in newborn is equal to adult. The average is $126.5^{\circ} \&$ ravge is $106^{\circ}-151^{\circ}$ according to Kate BR [21].

If the angle of inclination is greater than $125^{\circ}$, is termed as coxa valga or Alsberg's angle. (Hamill; Spencer) [22,23]. If the angle is decreasd termed as coxa vara.

According to Laville, [24] the angle is greater in females than males.

According to I Gilligan et.al, the NSA shows significant differences between ethnic groups, sexes \&ages.

Toogood PA [25] studied NSA among dry bone using digital method among American population \& observed NSA to be $129.2^{\circ}$ which is higher than the present study which may be due to racial variations among the two different populations.

The NSA is very high in neonatal age, and then gradually it decreases during development and reaches adult values [26].

Table 2: Values in the present study are compared with foreign and Indian studies.

\begin{tabular}{|c|l|c|c|c|}
\hline SI.No & \multicolumn{1}{|c|}{ Author } & Method & NSA & SD \\
\hline 1 & Amith R et al 2016 [27] & Dry bones & 121.2 & 6.2 \\
\hline 2 & Christoph kolja boese et al 2016 [9] & Dry bones & 163 & 0.9192 \\
\hline 3 & Radha Pujari 2015 [16] & Dry bones & 127.5 & 5.874 \\
\hline 4 & P.F. Umebese 2005 [28] & x-ray & 1210 & 6 \\
\hline
\end{tabular}

The present study, the mean neck shaft angle of dry femur was observed on left $123^{\circ}$, on right side $119^{\circ}$ and these results are correlation with Amith R (27) and P.F. Umebese (28).

\section{CONCLUSION}

The knowledge of Anatomy of proximal end of femur is very important for clinical and pathological states of hip joint and to design prosthe- sis for hip replacement. The clinical importance of neck shaft angle of femur lies in the diagnosis, treatment and follow up of fractures of the neck of femur, trochanteric fractures, slipped upper femoral epiphysis, development dysplasia of the hip and neuromuscular disorders of the lower extremity.

In children Genu varum is a deformity of the knee concerned with coxa valga causing bow legs and genu valgum is related with coxa vara causing knock knees and pesplanus (flat foot). The NSA is less than $140^{\circ}$ in cerebral palsy cases. Osteoporosis and fractures of femoral neck changes NSA.

\section{ACKNOWLEDGEMENTS}

The authors would like to acknowledge the help of Dr. S. Muralidhar reddy, HOD and Professor of dept. of Anatomy, NRI medical college, chinakakani.

\section{ABBREVIATIONS}

NSA - Femoral Neck Shaft Angle.

\section{Conflicts of Interests: None}

\section{REFERENCES}

[1]. Reikeras O, Hoiseth A. and Reigstad A, Fonstelien E. Femoral neck angles. Acta orthop. Scand. 1982;53:775-79.

[2]. Billing, L. Roentgen examination of the proximal femur-end in children and adolescents. Actu Radiol., 1954;Suppl.110.

[3]. Norman, 0. Matning av collumanteversionsvinkeln. En principiell diskusjon. Nord. Med. 1969;75:318.

[4]. Dunlap k., Shands A. R. JR, Hollister I. C. JR, Stuart gaul J. JR and Streit H. A.: A new method for determination of torsion of the femur. J. Bone Jt Surg. 1953;35-A:289.

[5]. Rippstein J. Zur Bestimmung der Antetorsion des Schenkelhalses mittels zweier Rontgenaufnahmen. Z. Orthop. 1955;86:345.

[6]. Reikeras o., Hoiseth A. and Reigstad A. Evaluation of the Dunlap/ Rippstein method for determination of femoral neck angles. Acta Radiol. Diagnosis 1985;26:177.

[7]. Chevrot A. Technique radiologique simplifite dans la mesure de l'angle d'anttversion du femur et de l'angle cervicodiaphysaire. J. Radiol. 1976;57:545.

[8]. Ian Gillian, supichya chandraphak et al. femoral neck-shaft angle in humans :variations relations to climate, clothing, lifestyle, sex, age \& side -AJ. 2013;223(2):133-151.

[9]. Williams PL, Warwick R, Dyson M, Bannister LH. Gray's Anatomy. USA: Churchill Livingstone;1989. 
[10]. Rickels T, Kruzer S et al. age and gender related differences in femoral neck- shaft angles - Poster No. 2279 ORS 2011 Annual Meeting

[11]. Maheswari AV, Jain AK, Singh MP, Bhargava SK. Estimation of femoral neck anteversion in adults: a comparision between preoperative, clinical and Xray methods indian J orthop. 2004;38:151-7.

[12]. Gudiera KJ, Ganey TM, Keneally CR, Ogden J. The embryology of lower-extremity torsion. Clin Orthop Relat Res. 1994;302:17-21.

[13]. Duncan RD. Developmental dysplasia of the hip In. In: Benson M, Fixsen J, Macnicol M, editors. Children's orthopedics and fractures. Churchill Livingstone; London: 2010. p. 435

[14]. Tian TP, Chen Y, Leow WK, Hsu W, Howe TS and Png MA. Computing neck-shaft angle of femur for X-Ray Fracture Detection. NMRC 2000.

[15]. Bobroff ED, Chambers HG, Sartoris DJ, Wyatt MP, Sutherland DH. Femoral anteversion and neck-shaft angle in children with cerebral palsy. Clin Orthop Relat Res. 1999;364:194-204.

[16]. Radha pijari, Ravi shankar G. et al. Evaluation of neck shaft angle of femur or dry bones. Journal of evaluation of medicals dental sciences 2015;4(32):5518-5522.

[17]. S.Delauvay, R.G Dussalt et al. radio measurates of dysplastic adult hips. skeletal radiology, 1997;26(2):75-81.

[18]. J.R Davids, T.W. Gibars, L.J pugh , \&J.W. Hardis. Proximal femoral gemeter before and varus rotational osteotamy in children with cerebral palsy and neuromuscular hip dysplasia, J. of padiatric orthopaedics, 2013;33(2):182-189.

[19]. Christoph kolja Boese et al. The modified femoral neck - shaft angle: Age \& sex- dependent reference values \& Reliability Analysis. Journal of Biomedical Research International, 2016; Article ID 86475627.
[20]. Humphry GM. The angle of the neck with the shaft of the femur at different periods of life and under different circumstances. J Anat Physiol 1889;2:273-82.

[21]. Kate.B.R. The Angle of femoral neck in Indian Eastern Anthropologist 1967;XX(1):54-60.

[22]. Hamill, J; Knutzen, K.M. Biomechanical Basis of Human Movement., USA, Williams and Wilkins. 1995;298-209.

[23].Spencer A. Practical Podiatric Orthopaedic Procedures, Clevland, Ohio college Of Podiatric Medecine 1978;21-23.

[24]. Christ lavelle 1974 An analysis of human femur American Journal of Anatomy, 1974;141:3:415-426.

[25]. Toogood PA, Skalak A, Cooperman DR. Proximal Femoral Anatomy in the Northeastern region Population. Clin Orthop Relat Res. 2009;467:876-85.

[26]. Laplaza FJ, Root L, Tassanawipas A, Glasser DB. Femoral torsion \& neck - shaft angles in cerebral palsy. Journal of Pediatric Orthopaeducs 1993;13:92-9.

[27]. Amith R et al., Morphometry of femoral NSA in dry femora of south india by computer assisted image analysis method, Int J Anat Res.2017;5(2.1):375358. ISSN 2321-4287

[28]. Umebese PF, Adeyekun A, Moin M. Radiological assessment of femoral neck shaft \& anteversion angles in adult Nigerian HIPS. Niger Postgrad Med J. 2005;Jun;12(2):106-9.

How to cite this article:
Aparna Gullapalli, Anil Kumar Inuganti. MORPHOMETRICSTUDY
OF FEMORAL NECK SHAFT ANGLE AND ITS CLINICAL
SIGNIFICANCE. Int J Anat Res 2017;5(3.2):4261-4264. DOI:
10.16965/ijar.2017.301 